\title{
Erratum to: Harvesting of microalgae biomass from the phycoremediation process of greywater
}

\author{
Hauwa Atiku $^{1}$ - RMSR Mohamed $^{1} \cdot$ AA Al-Gheethi ${ }^{1}$ - AA Wurochekke ${ }^{1}$. \\ Amir Hashim M. Kassim ${ }^{1}$
}

Published online: 28 November 2016

(C) Springer-Verlag Berlin Heidelberg 2016

Erratum to: Environ Sci Pollut Res (2016) 23:24624-24641

DOI 10.1007/s11356-016-7456-9

The Authors' names in the original article were not quoted correctly.

The correct names are indicated in this erratum.

The online version of the original article can be found at http://dx.doi. org/10.1007/s11356-016-7456-9.

\footnotetext{
RMSR Mohamed

maya@uthm.edu.my

Hauwa Atiku

atikuhauwa@yahoo.com

AA Al-Gheethi

alisaeed@uthm.edu.my

1 Micro-pollution Research Centre (MPRC), Department of Water and Environmental Engineering, Faculty of Civil \& Environmental Engineering, Universiti Tun Hussein Onn Malaysia, 86400 Parit Raja, Batu Pahat, Johor, Malaysia
} 